\title{
WHY SUPERMAN WILL NOT SAVE THE WORLD: THEORIZING THE RELATIONSHIP BETWEEN SUFFERING AND DC COMICS SUPERMAN
}

\section{Kwasu Tembo (a)}

(a) Independent researcher. Harare, Zimbabwe. Email: tembo.kwasu[at]gmail.com

\begin{abstract}
The hypothesis that there is an inextricable link between comic book superheroes and suffering would, to anyone with a cursory knowledge of superhero characters found in DC, Marvel, Image, Wildstorm and other houses, and their histories, ostensibly seem valid. This validity depends on which character one is applying said hypothesis to; the psychological and physical suffering of a Batman being more acceptable as such than that of a Plastic Man, for example. However, using DC Comics character Superman as a case study, this paper explores the inextricable link between Otherness, power, and suffering within the remit of the character's mythos. In order to do so, this paper refers to psychoanalytic concepts elaborated by Sigmund Freud in his text Beyond the Pleasure Principle (1922) as a way of demonstrating that despite the character's conventional appraisal as a positivist humanistic symbol of pure altruism, an insuperable, unimpeachable symbol of selflessness and good morality, there is in fact a fundamental link between Superman's 'tridentity' of selves (Clark Kent/Kal-El/Superman), the character's own suffering, and human suffering on a terrestrial scale, as represented within the numerous realities of the DC Comics Multiverse.
\end{abstract}

Keywords

Pain; Suffering; Power; Otherness; Superman; Waid; Freud; Pleasure-principle

This work is licensed under a Creative Commons «Attribution» 4.0 International License. 


\section{ПОЧЕМУ СУПЕРМЕН НЕ СПАСЕТ МИР: ОСМЫСЛЯЯ ОТНОШЕНИЯ МЕЖДУ СТРАДАНИЕМ И СУПЕРМЕНОМ}

\section{Тембо Квасу (а)}

(а) Независимый исследователь. Хараре, Зимбабве. Email: tembo.kwasu[at]gmail.com

\section{Аннотация}

Гипотеза о том, что существует неразрывная связь между супергероями комиксов и страданиями, кажется верной любому, кто хоть как-то знаком с супергероями DC, Marvel, Image, Wildstorm и их историями. Но правдивость этого утверждения зависит от того, к какому персонажу применена указанная гипотеза. Например, психологические и физические страдания Бэтмена больше подходят под эту гипотезу, чем страдания Пластичного Человека. Используя в качестве примера персонажа DC Comics Супермена, данная работа исследует неразрывную связь между Инаковостью, властью и страданиями в рамках мифологии персонажа. Для реализации подобного исследования, автор опирается на психоаналитические концепции, изложенные Зигмундом Фрейдом в его работе "По ту сторону принципа удовольствия" (1922 г.), чтобы показать, что, несмотря на традиционную оценку персонажа как гуманистического символа чистого альтруизма, непобедимого, безупречного символа самоотверженности и морали, на самом деле существует фундаментальная связь между "троичностью" Супермена (Кларк Кент/Кал-Эл/Супермен), страданиями персонажа, и человеческими страданиями в земном масштабе, как это представлено в многочисленных реалиях мультивселенной комиксов DC.

\section{Ключевые слова}

Боль; Страдание; Власть; Инаковость; Супермен; Уайд; Фрейд; Принцип удовольствия

Это произведение доступно по лицензии Creative Commons «Attribution» («Атрибуция») 4.0 Всемирная 


\section{INTRODUCTION: SUPERMAN AND SUFFERING}

There are many ways to describe 'suffering'. Suffering can refer to physical and/or mental pain, or more broadly to any and all unpleasant sensations and/or emotions. In view of this definition, the proposition that there is an inextricable link between Superman and suffering might appear antithetical to arguably the most recognizable post-industrial popcultural image of hyper-masculine, androcentric strength. While it is true that superheroes are not entirely identified with or defined by suffering, this essay will argue that it is an inextricable element of the character's narrative and thematic profile, as well as an irreducible element of Superman's entire mythos. The consequences of the relationship between Superman and suffering, as I will show, are important because they call into question the character's historico-cultural value as an icon of heroic altruism.

How does a near physically invulnerable being like Superman not just engage with the suffering and pain of others, but experience or suffer pain itself? My understanding of 'suffering', with regard to Superman, is indebted to the etymology of the English word "suffer", derived from two Latin words, 'sub' and 'ferre', meaning literally "to carry under." Another Latin meaning derived from the combination of 'sub' and 'ferre' conveys the psychological sense of suffering I will explore in this piece. These two words can also signify "to take upon oneself." By suffer, therefore, I am referring to a confluence of psychological and emotional neuroses that form the core complex at the heart of the character predicated on onto-existential difference or Otherness the character always carries, literally and figuratively, under its performance of human being as Clark Kent, and a need to belong which it takes upon itself as Superman.

While most readers are familiar with Superman as 'he', from the character's creator Jerry Siegel through to contemporary writers, I need here briefly explain my use of the term 'it' in reference to Superman throughout this paper. Indeed, it might seem distracting or counterintuitive to do so. However, the fact that Superman is an alien is taken as a first principle here. It is an extra-terrestrial creature that expresses many seemingly identical superficial traits with human beings that, however convincing, must not overlook the fact of Superman's essential difference from any and everything human. Furthermore, 'he', when considered fully, only accurately refers to one third of the personae 'worn' by 'Superman/Kal-El,' namely 'Clark Kent.' My justification for discussing Superman by using the term 'it' is due in part to the underlying ethic of this 
thesis being xenological. If, for example, I am to consider Fredric Jameson's xenological approach to reading texts that feature alien beings seriously, which he elaborates in Archeologies of the Future: Utopia and Other Science Fictions (2007), then I think that the retention of the term "it" is important because it highlights the fact that Superman is an alien. Regardless of the methodological approach one brings to bare on the character, regardless of how complex or nuanced, it would not change the fact that, diegetically speaking, the character is an alien. The combination of this fact and my wish to maintain a careful sensitivity toward xenological appraisals of Otherness would call for a strategy that does not hem up the onto-existential complexities of the character by simply referring to an alien being as "he" because it looks like a robust human man. To do so would simply be an inaccurate retention of anthropocentric privileging, a privileging that the central hypothesis seeks alternatives to. To be clear, I do not believe that referring to Superman as 'it' objectifies the character. On the contrary, I argue it draws attention to the fact that the character represents an interesting alternative to any human/inhuman dialectic precisely because it is both in interesting and challenging ways. Precisely one of those ways pertains to the value of human belonging to an alien orphan, and the philosophical and psychoanalytical consequences thereof.

The overarching goal of this paper is to theorize suffering in relation to Superman through Sigmund Freud's discussion of the relationship between suffering, pleasure, and pain in Beyond the Pleasure Principle (1922). Here, I acknowledge the fact that it could be argued that referring to Freud in this capacity seemingly reinserts or re-frames Superman within messianic discourses, something this paper seeks to avoid. Instead, this paper is less concerned with reading Superman's pain as some figuration of a crying god, so to speak. Instead, this paper concerns itself with exploring the problem of Superman's pain as a question of the limits of experience for a radical Other living amongst human beings. As a further conceptual apparatus, my theorization of suffering in Superman will refer to the psycho-physical phenomenon of algolagnia - where the body derives pleasure from pain - as a way of exploring the inverse logic at play between pleasure, desire, pain, and suffering in the character's specifically heroic mythos. In pursuing a psychoanalytical reading of the relationship between suffering and Superman, the goal of this paper is to move away from the reductivism of messianic interpretations of the character's relationship with various forms of suffering. Referring to one of the most influential appraisals of the nature of Superman's suffering in contemporary comics, I seek to join Mark Waid's views with psychoanalytic concepts to expose and explore the rich psycho-emotional, philosophical, and sociopolitical ramifications of suffering in Superman. 


\section{PERMANENT, DARK, AND OBSCURE: A PSYCHOANALYTIC READING OF THE RELATIONSHIP BETWEEN SUPERMAN AND SUFFERING}

It should be clearly stated at the onset that this essay is intended to be read in and amongst all other scholarly and creative efforts that seek to present Superman, and characters like it, beyond the delimitations of narrow messianic approaches. This paper acknowledges that it could be argued that the use of Freud here brings us right back to the figure of the messiah as, the totemic horde, for example, and the sacrifice of the Primal father represents the roots of religion. This, and ancillary thoughts subtending it, is a theme taken up by many scholars and works including Peter Coogan's Superhero: The Secret Origin of a Genre (2006), Christopher Knowles' Our Gods Wear Spandex (2007), and Grant Morrison's Supergods: Our World in the Age of the Superhero (2012), who/which have argued that the confluence of concepts including power, radical Otherness, and the ostensibly altruistic and morally/ethically humanitarian deployment of those powers unavoidably carry with them messianic subtexts. In a countermove, this paper seeks to present a more nuanced psychoanalytic theorization of what it means for a being like Superman to suffer. The reading developed in this analysis has less to do with ideas that equate Superman with the figure of the messiah, but rather that the kernel of any and all suffering experienced by the character pertains to the conflict and tension between the character's power and uncanny Otherness, and the numinous draw of the phenomena of belonging.

Let me begin by addressing one of a possible range of messianic associations that emerge from a comparative analysis of Freudian psychoanalysis and Superman. Freud's essay "Totem and Taboo" (1919), which explores the primal horde and the sacrifice of the primal father as the seeds of religion hence the messiah myth, presents an obvious link between psychoanalysis and Superman within the analytical remit of the concept of suffering. In a sense, Superman can be regarded as a totem of suffering for many readers: a being who suffers on behalf of those less powerful. According to Freud, the totemic father is

used in the attempt to assuage the burning sense of guilt, and to bring about a kind of reconciliation with the father. The totemic system was a kind of agreement with the father in which the latter granted everything that the child's phantasy could expect from him, protection, care, and forbearance, in return for which the pledge was given to honor his life, that is to say, not to repeat the act against the totem through which the real father had perished (Freud 213). Like the totemic surrogate father, 
as a symbol of forbearance, justice, truth, and altruism, Superman is typically seen as functioning in a similar way. The most conventional pop-cultural image of Superman is an invulnerable being with an invulnerable sense of moral probity which dedicates its vast powers and indefatigable spirit to the purpose of safeguarding the downtrodden and holding the unjust in contempt of the so-called inviolable laws enshrined in the constitution of the United States of America. Like religious totemism which obfuscates the originary violence of sacrifice, murder, and cannibalism of the primal father that is the true origin of the religious system, Superman's symbolic super-subjective position of perfect morality, and its latent totemic quality helps "gloss over the real state of affairs and [...] make[s] one forget" the problematic confluence of invulnerability, power, and subjective and indeed idiosyncratic morality the character simultaneously embodies and problematizes (Freud 213). In this sense, the humanities of the DC multiverse's reliance on Superman as a symbol of two central ideals of modern Western civilization summarized as 'truth' and 'justice', makes their saviour, as well as their society it protects, built and sustained by a shared complicity in the character's sense of guilt at seeking belonging over true justice. As my argument unfolds, its central contention will be that Superman's so-called good works can be described as a morality "based partly on the necessities of society and partly on the expiation which this sense of guilt demands" (Freud 213).

When viewed alongside the problem of suffering in the character, I posit that the way in which one views how Superman suffers reveals her/ his primary understanding of the nature of the character; that is, whether Superman is more symbol than person or vice versa. In order for the term 'superhero' to apply to Superman, the character has to either suffer or engage with suffering in some form. By this I mean that as a hero, Superman must seek out, intervene, and ameliorate suffering on the many earths of the DC multiverse. In numerous instances, this involves Superman suffering directly as well, be it that the character is beaten bloody in a brawl with Lobo or Darkseid, weakened by a red sun or kryptonite, or hurt by magic, for example. Across the range intimated by these two poles of suffering the character experiences as a hero, suffering for a cause, for the innocent, for the downtrodden are part of the Superman's mythos. How is the character to do so? With a stoic acceptance of suffering and terror? A distanced abstraction couched in the heightened objectivity a physically uncanny alien living among humanity might be privy to? If this is the case, the latent assumption here is that suffering, both psychological and physiological, are phenomena exclusive to persons. While Superman looks like a robust human male, the character is an alien from the fictional 
planet Krypton that was destroyed in an apocalyptic geological cataclysm. On the many earths of the DC multiverse, Kryptonians have amazing powers as a result of exposure to the yellow suns which said earths typically orbit. These include super speed, super olfaction, x-ray vision, flight, physical invulnerability, and possession of a super brain. In the wake of the destruction of Krypton, however, missing from this panoply of powers is a cultural referent, a people, a language, a history and therefore a sense of belonging. While Superman's avuncular pseudo-messianic image of being an near-omnipotent optimist, a hard-working humanitarian, and a powerful philanthropist would indeed suggest that the character engages with suffering in a stoic albeit positive manner, this does not change the psychological and emotional suffering the character experiences within the cultural and sociopolitical framework superheroes operate within. In other words, while one might argue that suffering and death are basic human problems and the fact that Superman is a nearly invulnerable alien means than as a non-person being cannot suffer in the same way as a human being, does not mean that a Kryptonian cannot suffer in principium.

On the page, the relationship between Superman and suffering has its most pronounced developments in DC superhero comics of the $1980 \mathrm{~s}$. During this period, the character suffered, endured, and overcame the personal tragedy of losing not only Kara Zor-El/Supergirl, its 'cousin' during the major Crisis on Infinite Earths (1986) story arc, but also the death of Jonathan Kent, the character's surrogate/adoptive/terrestrial father in "The Last Days of Ma and Pa Kent" in Superman Vol. 1, No. 161 (1963), and "The End" in Superman Vol. 2, No. 77 (1993). In each case, the character was made to face and subsequently overcome the abyssal plane of nihilism. Alan Moore and Dave Gibbons, however, took a distinctly psychological approach to the problem of Superman's suffering. In September 1985, Superman Annual No. 11 featured a story entitled "For The Man Who Has Everything." In this story, Wonder Woman, Batman, and Robin travel to Superman's Fortress of Solitude to celebrate its birthday. Upon arrival, they discover their colleague in a catatonic state, with an enormous alien plant life-form attached to its chest. The plant, called a Black Mercy, attaches itself to its host/victim in a form of symbiosis. It feeds off of the victim's 'bio-aura' while simultaneously accessing the victim's unconscious mind, allowing it to feed him/her with a logical simulation of the 'happy ending' they desire most in order to keep the victim docile. Initially, the 'happy ending' Superman envisions is a simulation of what the character's life would have been like had Krypton never been destroyed. Said phantasy consists of Superman being happily married to the former Kryptonian actress Lyla Lerrol, a successful archaeologist, and a father of 
two. While Superman is under the thrall of the Black Mercy's simulation, Wonder Woman fights the evil space tyrant Mongul who is responsible for Superman's enchantment. Simultaneously, Batman and Robin attempt to free Superman from the plant's mind control. The vision that the Black Mercy feeds Superman is not perfect, however. As Superman's will struggles against the plant's control, the 'happy ending' becomes increasingly horrific. It is revealed that Superman's elderly father Jor-El was dismissed from Krypton's Science Council after its theory of the planet's destruction was disproved. This left Jor-El an embittered member of a violent and extremist reactionary religious faction called The Sword of Rao, whose ethos involves crusading against modern technocentric Kryptonian society. Eventually, Superman fights off the Black Mercy's thrall. Enraged, confused, and heart-sick, Moore and Gibbons show the reader a rarely seen wrathful and murderous Superman. After an intense fight ensues, Robin saves the day by throwing the Black Mercy at Mongul, leaving the interstellar warlord to suffer its torments in turn. In terms of the relationship between Superman and suffering, this story is important in suggesting that Superman's most poignant form of suffering is not located in the physicality of its power or, with the aid of devices like kryptonite, its powerlessness. Instead, Moore suggests that it is the psychological trauma of presenting the character with the opportunity, real or virtual, of being able to choose to be other to itself, to be 'normal', to be totally human, all all too human and then subsequently taking that option away or worse, revealing it to have always-already been spurious, is the source of Superman's truest and most resonant suffering (Weldon 215-16).

\section{SAVED FROM SUFFERING BY A SUFFERING CHAMPION: SUPERMAN, PAIN, POWER, AND SUFFERING}

In "The Real Truth About Superman: And the Rest of Us Too" (2005), Mark Waid describes Superman as a cultural institution, almost universally known as not only the progenitor of modern superheroes, but as a symbol for a "never-ending battle" for truth and justice. In this way, Waid sees Superman as the closest "contemporary Western culture has yet come to envisioning a champion who is the epitome of unselfishness. [As a direct result,] the truest moral statement that can be made of Superman is that he invariably puts the needs of others first" (Waid 3). Waid's description suggests that the relationship between the character, its power, and its use thereof are commonly viewed as fundamentally mediated by a moral, and particularly, altruistic ethos. Similarly, in a section titled "What Is A Superhero?", Fingeroth goes as far as to suggest that Superman, like 
even the most disparate comic book superheroes - the examples he gives are Thor and Batman - are functionaries of the same fundamentally moral ethic (Fingeroth 16-7).

However, in Superheroes: A Modern Mythology (1992), Richard Reynolds notes that Superman, or any other super-powered character who chooses to pursue a so-called morally righteous or pro-social agenda, are "by and large not upholders of the letter of the law; they are not law enforcement agents employed by the state" (Reynolds 74). This fact makes Superman's punitive use of power somewhat paradoxical not only in terms of legal malpractice, but also because it seems odd that a being of power and Otherness would elect to subjugate its power to any ideal that prohibits the full expression of said power and/or Otherness. I argue that the conservative civic-mindedness of mainstream comic book superheroes like Superman is a direct consequence of an interpellation of superpower into politics. By the term interpellation, I am referring to the process by which individuals are hailed and made subject to an ideological framework that mediates their experience of subjecthood as well as the subjecthood of others. As a result, the disruptivity of Superman's power and Otherness has become entombed in the various political agendas and ideals of readers carried into the fictional worlds of the DC multiverse over time. In Superhero: The Secret Origin of a Genre (2006), Peter Coogan provides a near identical definition of superhero as Fingeroth's stating that a superhero is "a heroic character with a selfless, pro-social mission" (Coogan 30). This trend is further evidenced in Jeph Loeb and Tom Morris's definition of a superhero in Superheroes and Philosophy: Truth, Justice, and the Socratic Way (2004) who describe Superman's example of a genuinely altruistic Way as one which reminds as much as it does show readers that "the superheroes work for not just people who appreciate their efforts, but often for people who criticize and revile them. They don't do what they do because it's popular. They do it because it's right" (Loeb \& Morris 28: italics mine).

One can see a pattern emerging, one that I argue tends toward reductively, directly or indirectly, fusing the concepts of superpower, moral and ethical programs of altruism, and pro-social agendas in a way that holds with the demands of moral excellence inherent in a narrow humanistic conceptualization of the term 'hero.' Regardless of how thematically and aesthetically nuanced texts like The Dark Knight Returns (1986), Watchmen (1986), or Miracleman (1985) may be in terms of assessing the tensions inherent in the above concepts, they were, until the late 1980s, rare instances. Texts like Moore and Millers' in which the radical consequences of the relationship between power, utopia and dystopia are taken 
to their radical conclusions in characters like Dr. Manhattan, Miracleman, or Superman itself have, for the preponderance of modern comic book history, been typically only partially engaged with or alluded to outright in favor of a morally essentialist understanding of comic book superbeings. This approach has become the principal convention of the genre and character type in the mainstream.

I contend that one cannot properly consider the question of an invulnerable being's suffering without also considering why it does what it does: one cannot holistically consider this question without considering what Superman desires. What can human socio-political and cultural reality in which "unrestrained capitalism always wins, where politicians always lie, where sports idols take drugs and beat their wives, and where white picket fences are suspect because they hide dark things" have to offer a being like Superman? (Waid 6). In Paul Dini and Alex Ross' Superman: Peace on Earth (1999), the reader is lead to believe that above all else, what Superman wants most is to be a sociopolitical and cultural catalytic agent, not a messianic idol, but a moral example to spur humanity on to revalue its various ideologies and thereby transform them for the greater good of the entire species. After helping officiate the beginning of the Christmas season celebrations in Metropolis, the character encounters a young woman suffering from starvation. This inspires Superman to investigate the problem of world hunger. Before Superman can use its immense physical power, political influence, and iconographic celebrity to redress this longstanding problem of human being, the character first reflects:

I think back to my father. As a farmer, he had a natural understanding for the Earth. I remember him telling me this world is capable of providing for all its creatures. Even now, with so many people, there exists enough food for everyone. 'The problem.' Pa used to say, 'is people, as far back as we go, we've always had problems with sharing. Seems everyone's too busy holding on to what they've got to care how their neighbours are doing.' Pa said it would take a special individual with no personal agenda to make everyone realize what the world has to offer. Someone who could put his own needs aside to help the greater good. I don't pretend to think I am that person, though I have always tried to be there for others. To look upon my powers as a gift, not mine alone but for anyone who needs them. Over the years I've helped as many people as I could. It's not my place to dictate policy for humankind. But perhaps the sight of me fighting hunger on a global scale would inspire others to take action in their own ways. Its certainly an example worth setting." (Dini and Ross n.p)

However noble or naive one may find this symptomatic example of the character's utopian vision of humanity's potential in this and count- 
less other comics, Superman's humanism is not without problems. Due to the character's supersenses, which are tantamount to extreme powers of observation, it is impossible to believe that the character would not be constantly bombarded with the horrors of human being on earth. Moreover, Superman is not only exposed to these same horrors but actively pursues them. As an agent of the media apparatuses of the State in the form of Clark Kent, the character constantly monitors and reports on violence, exploitation, prejudice, corruption, and human ecological negligence daily. In view of the aforementioned positive appraisals of the character, the question here is primarily concerned with Superman's value as such an example in the face of the continued suffering of the human race. If the conventional appraisal of the character is to be believed and neither material wealth, possessions, fame, or laurels of any kind impel Superman's actions, then what can a diegetic earth and its humanity, seemingly resolute in its self-annihilating ways as it might appear to an alien, offer Superman? The answer Waid offers is predicated on Superman's superlative condition and the solipsistic sense of extreme isolation that results. The physical and experiential intractability of power and uncanny Otherness from the character produces a condition of terminal displacement, permanent fracture, and a sustained existential crisis of self-understanding. The solution to this inextricable suffering the character always-already experiences being on earth is, according to Waid, belonging. In response, I argue that belonging is not so easily achieved, and may be impossible for a being like Superman on an earth resembling the reader's sociopolitical, economic, and cultural reality. For Superman, on an earth resembling the reader's sociopolitica, economic, and cultural reality, the question of belonging always redounds to whether or not the character is willing to suffer repressing the fundamental forces of its being namely, its power and Otherness.

The conventional understanding of Superman holds that the three things the character wants most are; 1) 'Truth', 'Justice', and peace for all humanity, 2) Lois Lane, and 3) to belong. Waid suggests that, above the character's desire to be a shining example for the potential of a utopian Tomorrow for the earth and all life therein, or even to be able to be wholly with Lois without the always-already present interruptions of its power (Superman) and Otherness (Kal-El), it is the third aspect of the character's desires that is strongest. Setting aside the problems inherent in equivocating human psychology with extraterrestrial behaviour here, Waid sites Abraham Maslow's "A Theory of Human Motivation" (1943) in suggesting that, on a hierarchy of needs, just below various physiological 
needs, beginning with nourishment, it is the psychological need to belong that is most powerful in human beings:

\begin{abstract}
Hunger, the base need to survive, can be viewed as a primary condition of human being. It is a need that always recurs and can only, despite quantity or quality of nourishment, be momentarily delayed. In Peace on Earth, Superman forgoes the Yuletide celebrations held at the Daily Planet. Instead, the character conducts research in the office archives into the problem of world hunger, its causes, effects and possible solutions. Interestingly, when examining disturbing photographs of malnourished, famine-ridden children and various other victims of hunger, Superman muses: "it's ironic. I don't need to eat. I will never know HUNGER. I don't know what victims of starvation feel. I can't decide if that is a blessing or a curse (Dini and Ross n.p)
\end{abstract}

In this sense, this most basic struggle of human being has "virtually no significance to Kal-El, whose cellular structure derives its nourishment not from food but from solar energy" (Waid 8). Due to the character's invulnerability, Superman cannot truly understand the human need for safety, for shelter, or for security. Such concerns, drives, and instincts fundamental to the condition of being human - start to mean less and less when one considers the fact that in the history of the Superman mythos, the character has been illustrated as being able to withstand a direct thermonuclear detonation, flying through black holes, and making diamonds out of coal with its bare hands. Here, Moore's insights become important because while pain may be in the body and suffering in the mind, Superman raises the onto-existential and psychological question as to whether a body that cannot feel pain, under most circumstances relative to an average human being, but only experience the most pronounced types of pain as psychological phenomena truly understand suffering at all. If the character's ontological and existential experiences are not reducible to anthropic physiological needs, drives, or instincts, by a process of elimination, one assumes that Superman's need to belong is the true primary motivation for its actions and the essence of the strength of the character's psycho-social, cultural, and ideological bonds (and desire to maintain them) with human being. It would seem perfectly logical to make such as assumption because why else would Superman bother being Clark Kent, an individual who works, lives a city life, observes and subjects itself to the sociopolitical, economic, and ideological structures of a type of being fundamentally other, and in many ways lesser, to its own? Why would the character not decide to abandon earth, or any diegetic representation of a planet and its inhabitants, and explore the vastness of space for as long as its interest holds and radiation from yellow stars re- 
mains accessible to it? The assumptive answer would be that Kal-El connects with a world paradoxically, that is, by using its alien heritage and power to participate and integrate within humanity.

This conventional view upheld by those quoted above and numerous others betrays a Romantic blindness that seeks to overlook the fact that because of the character's power, uncanny, human-like body, and Otherness, Superman is, both onto-existentially and psychologically, an inescapably paradoxical character. I argue that this kind of Romantic reading of Superman negates what I believe to be one of the most poignant aspects of the character, namely its tragic and circuitous existence within a reality it has the power to change, but psychologically forbids itself from changing. Instead, the character's power is spent perpetuating the conditions of its own suffering and its failure to act decisively to address the trauma and tragedy of not only being a powerful and uncanny Other, but to change what it ultimately means to exist on a diegetic earth on which a being like Superman exists. The extreme implication here is that Superman cannot save the world because the character's need to belong to the world as it recognizes it - with all its aporias, problems, and hunger for more, for better, for an alternative, for change, for power -, as well as the pleasure it takes in it, outweighs the character's will to decisively change it. I argue that Superman's refusal to actively and unceasingly change the world can only be construed as a choice, one that it carries under and takes upon itself. It is a choice with moral and existential consequences that evoke Thich Nhat Hanh's insight that individuals have difficulty abandoning their suffering, seeking instead a familiar suffering or the familiarity of suffering out of fear of the unknown. For Superman, the fear is of the unknown of radical isolation, a fear that, in turn, propels the character's need for belonging and its most adverse effects not only to itself, but the human denizens of DC's Multiverse.

\section{AT THE MERCY OF A SUPERBEING'S PLEASURE: PLEASURE, PAIN, AND SUFFERING IN SUPERMAN}

What is at stake here are the repercussions of the pleasure the character takes in being Superman and Waid's assumption that Superman has its need for belonging satisfied precisely by being Superman. The conclusion to be drawn from Waid's propositions is that Superman cannot decisively intervene in changing the world because the character's need or desire to belong, and its need or desire for a concrete selfhood, subjecthood, and identity are inextricable from not only the existence of the fundamental torments and suffering experienced by human beings, but also their 
maintenance and perpetuation. When viewed in this way, the requisite suffering needed for Superman to fulfil its dream of belonging, and the human need for the alleviation of suffering being fulfilled by being Superman - a partisan reactive agent of moral and ethical punitive 'justice', as well as ideological,and repressive action - is problematic when the character is valued as a so-called hero. This is because ultimately, the character's need to belong and the pleasure it derives from it is, fundamentally, a hallucination, a spectral arrangement predicated on and exacerbating the suffering of those it 'serves' in serving itself. This tautological and psychologically paradoxical logic at play in Superman's relationship to suffering questions the character's humanist status. Despite the character's myriad and vast powers, and the potential therein, and despite its noble intentions and idealistic fantasies of humanity's so-called instinct for 'good', both Superman and the diegetic humans it saves act in a way that perpetuates the need for a saviour: Superman suffers humanity, and humanity suffers Superman. Against the conventional appraisal of the character's hierarchy of needs, I argue that this is the truth about Superman and about ourselves. This is what is carried under the azure, crimson, and gold of the bright livery and equally bright image of power, stability and altruism the character projects. This is the permanent, obscure, and dark truth of the Superman's terrestrial diegetic experience.

My assessment of the character's suffering - a type of undercarriage of an obsession/desire for belonging - as being both self-sustaining and, ultimately, ideologically repressive and unethical, presents Superman not as a god, but as a neurotic, in psychoanalytical terms. It is interesting to note, as Carl Jung does in Word and Image (1979), that neurosis is substitutive, that is, "neurosis is always a substitute for legitimate suffering" (Jung 123). In this way, the psycho-emotional suffering Superman carries as a result of the ultimate impasse between its Otherness and the desire to belong to a people and planet in which its Otherness is always-already present regardless of however well sublimated that Otherness is in the performance of humanity, substitutes and extends the suffering of those it seeks to, ironically, protect from suffering. In this sense, belonging is a human solution for an alien problem, one that results from an incongruence between what it is taught to be and what it always-already is and is always-already becoming. Worse, perhaps, is that the only conclusion to be drawn from my criticism of Waid here is, as Fredrick Jameson puts it in Archeologies of the Future: Utopia and Other Science Fictions (2007), that "the alien, fully assimilated, its Difference transmuted into Identity, will simply become a capitalist like the rest of us" (Jameson 141). 
The suggestion that Superman's connection to earth and human being as based on a desire to belong conforms to Freudian conceptualizations of desire that link desire, lack, and the individual subject in a few respects. Superman, according to our above hierarchy of the character's desires, wants to belong to the human race more than it wants to use its power to change being on its adoptive world because it lacks an origin, an inheritance, a people, culture, and language of its own in a lived, communal, non-archived and/or static sense. While Superman has referent facsimiles of these phenomena in the form of the history of Krypton and its people chronicaled and archived on Kryptonian sunstones - crystalline structures used as power sources and data storage devices - in the Fortress of Solitude, Superman's lived experience as a Kryptonian is typically portrayed as singular and radically isolated. The character's continual desire for the inclusivity, community, and belonging intimated in human being is predicated on this absence or lack of an origin (Krypton). As such, for Superman, human being functions as a prosthesis of origin. Referring to Beyond the Pleasure Principle and algolagnia, I will now briefly consider the ramifications of what Superman's essential need to belong and the modicum of pleasure it derives from it in Freudian terms.

Freud defines the pleasure principle as follows, "any given process originates in an unpleasant state of tension and thereupon determines for itself such a path that its ultimate issue coincides with a relaxation of this tension i.e with avoidance of 'pain' or with production of pleasure" (Freud, Beyond 1). Inherent in this construction is a dialectical opposition between stability and instability in that, the movement toward pleasure can be viewed as a movement toward stability up to a threshold. Pain, antithetically, departs from the movement toward the pleasure of an equilibrium. Freud's definition of the pleasure principle, much like Arthur Shopenhauer's assessment of existence in The World as Will And Representation (1859), presupposes that human existence is essentially negative. From this pessimistic viewpoint, the motivation of one's actions is alwaysalready the alleviation of the trauma of being. This alleviation is always imaginary, or at least metaphorical, as much as it is temporary. It is imaginary in the sense of the various problems associated with language's claim to pure representation exemplified by the arbitrariness of the semiological sign. After all, it is through symbols and language that one first understands his/her/its predicament and through which one subsequently attempts to act in response to it. It is temporary in the sense that the desire to alleviate the traumas of being can never be totally delayed. Pain, suffering, physical, psychological, emotional and so on recur like a hunger that haunts one throughout his/her/its existence. As such, the concepts of 
pleasure and pain do not in and of themselves refer to any pure experience. For example, the algolagniac derives pleasure precisely from pain, typically pain focussed at the conventionally accepted site of pleasure, that is, an erogenous zone.

For Freud, the pleasure-principle is challenged by the supremacy of the instinct for self-preservation, which ultimately supersedes the pleasure-principle, replacing it instead with what Freud calls a reality-principle (Freud 6). The reality principle is not totally divorced from the movement toward the maximization of pleasure and a movement toward stability and equilibrium, but it sublimates it in such a way as to differ the attainment of the goal of pleasure. In this way, the reality-principle "demands and forces the postponement of satisfaction, the renunciation of manifold possibilities of it, and the temporary endurance of 'pain' on the long and circuitous road to pleasure" (Freud 6). The reality-principle, as such, facilitates a breakdown of the initial dialectic of pleasure and pain whereby each phenomena is able to produce the other and contains, reflects, and necessitates the other. For example, one may derive satisfaction from using one's power to make some other submit to one's own Will. This desire, however, directly conflicts with the predetermined laws, morals, ethics, and good modes of behavior through which the subject must exist and express him/her/itself and, at once, has synthesized and internalized to mediate such disruptive, forceful, powerful desires. What results is the repression of such desires by the ideologically determined codes of normal, good, or acceptable behavior. Desire, which is as such also a form of power, is cut off, suppressed from the possibility of its actualization. If, however, the suppressed desire fights its way through "along circuitous routes to a direct or a substitutive gratification, this success, which might otherwise have brought pleasure, is experienced by the [subject] as 'pain'" (Freud 7). The pain of the attainment of pleasure is centered on a splitting, a betrayal. The subject feels pain from the actualization of a desire that disrupts the sanctioned mode of being and is in this way a pleasure that is not permitted, or should not be permitted, by the dictates of language, morality, ethics and so on to be experienced as such, as pleasure. Pain, in this way, is a pleasure that cannot be experienced as pleasure.

What does a Freudian excursus on psycho-emotional algolagnia mean for a being whose existence and the very power of that existence disrupt and delay almost infinitely the human processes of pain, pleasure, the perception and anticipation of both, as is the case with the concept of danger? In other words, how do pleasure, pain, desire and any and all suffering produced therefrom function, if at all, in Superman? What is at 
stake in the character's mimetic appropriation of these human phenomena and the processes of their perception, interpretation, and response? What does the Shopenhauerian, that is pessimistic, world view that underlies human being mean to a superbeing, one that does not, on the one hand, feel fear or hunger but, on the other hand, according to Waid, suffering in the form of an extreme sense of loneliness? If, paraphrasing Karl Marx, the only antidote to mental suffering is physical pain and Superman cannot feel physical pain in the same way humans can, what antidote for its acute psycho-emotional suffering can there be? I would conclude by suggesting that the concept I have put forward, namely Superman-as-algolagniac, is an index of a wider problem; namely, that that which gives Superman a modicum of pleasure, illusory, delayed, distanced, and temporary as it may be, is simultaneously the source of the pain and the circuitousness of its existence. In this way, the active pursuit of a sense of belonging, the act of being Superman, and the situation of its power on a diegetic earth invariably perpetuates not only the character's own suffering, but also the suffering of billions of DC's human beings across its multiverse who look up with joy, relief, wonder, and adulation at the coming of the Superman. This is the darkest irony of Superman. If it derives a sense of pleasure from being Superman and helping others, as Waid posits, then this pleasure is irreducible from the pain, misery, suffering, and fear of those it saves: its alien pleasure is therefore indivisible from human pain.

\section{CONCLUSION: THE GLOAMING PAIN}

It is important to keep in mind that within the remit of the character's historically consistent origin story, Superman was not sent to a diegetic earth with any agenda or mission. It was launched into space primarily under the aegis of survival. As such, the character was not forced or asked to be or, more importantly remain Superman by the diegetic humans it encounters. It chose to accept its self-determined ideological, moral, and ethical mission, as well as to use its power exclusively in the service of this mission, by resolutely aligning its power with this terrestrially determined telos, suffering it, simultaneously carrying it under and taking it upon itself. As a result, there can be no experience of pleasure without the simultaneous experience of pain for Superman. The pain produced by its pleasure in serving humanity produces an existential condition of crisis in which Superman's sense of happiness, pleasure, belonging, or identity is/are inextricably made conditional on the continual suffering of those its serves as much as its own suffering is produced and perpetu- 
ated by the displacement inherent in its superlative condition, its power and Otherness. They contain and (re)produce one another. Superman is in this way an algolaniac whose pathologically neurotic need for belonging calls into question the character's status as a paragon of altruistic action. When reassessing the character's mythos, and by extension any comic book superbeing with equivalently radical powers and Othernesses, one must ask themselves whether Superman is actually in the business of saving the world, preserving it, or perpetuating and safeguarding its own decay for the sake of its own pleasure. If the object of Superman's desire is to truly save or change the world, as the character often professes, the attainment of this desire is, at least psychologically, always-already delayed by its need to belong. In the last instance, a psychoanalytic reading of the character reveals that even superbeings get caught up and suffer human neurotic webs on diegetic earths and, in fact, serve to exacerbate them in their activities as superheroes. In the last instance, the utopian potential of a resplendent Tomorrow inherent in the character's power and Otherness is overcome by its psychological need to belong to the suffering of the never-ending battle of Today.

\section{References}

Coogan, P. M. \& O'Neil D. (2006). Superhero: The Secret Origin of a Genre. Austin, TX: MonkeyBrain Books.

Fingeroth, D. (2004). Superman On The Couch: What Superheroes Really Tell Us About Ourselves and Our Society. New York: Continuum.

Freud, S. \& Hubback, C. J. M. (1922). Beyond the Pleasure Principle. London: The International psycho-analytical Press.

Freud, S. (1919). Totem and Taboo: Resemblances Between the Psychic Lives of Savages and Neurotics. Routledge.

Jameson, F. (2005). Archaeologies of the Future: The Desire Called Utopia and Other Science Fiction. New York: Verso.

Jung, C. G. (1979). Word and Image. New York: Princeton University Press.

Lawrence, J. (2006). You Will Believe: The Cinematic Saga of Superman. Warner Brothers Pictures.

Loeb, J, \& Morris, T. (2005). Heroes and Superheroes. In T. Morris, M. Morris and W. Irwin (Eds.) Superheroes and Philosophy: Truth, fustice, and the Socratic Way (pp. 11-21). U.S.: Open Court Publishing Co.

Moore, A. and Gibbons, D. (1985). Superman Annual Vol.1, No. 11. New York: DC Comics.

Reynolds, R. (1994). Super Heroes: A Modern Mythology. Jackson: University Press of Mississippi. 
Ross, A. \& Dini, P. (1999). Superman: Peace on Earth. New York: DC Comics.

Waid, M. (2005) "The Real Truth about Superman: And the Rest of Us Too. In T. Morris, M. Morris and W. Irwin (Eds.) Superheroes and Philosophy: Truth, Fustice, and the Socratic Way (pp. 3-11). U.S.: Open Court Publishing Co.

Weldon, G. (2013). Superman: The Unauthorized Biography. Hoboken, N.J.: Wiley.

\section{Список литературы}

Coogan, P. M. \& O'Neil D. (2006). Superhero: The Secret Origin of a Genre. Austin, TX: MonkeyBrain Books.

Fingeroth, D. (2004). Superman On The Couch: What Superheroes Really Tell Us About Ourselves and Our Society. New York: Continuum.

Freud, S. \& Hubback, C. J. M. (1922). Beyond the Pleasure Principle. London: The International psycho-analytical Press.

Freud, S. (1919). Totem and Taboo: Resemblances Between the Psychic Lives of Savages and Neurotics. Routledge.

Jameson, F. (2005). Archaeologies of the Future: The Desire Called Utopia and Other Science Fiction. New York: Verso.

Jung, C. G. (1979). Word and Image. New York: Princeton University Press.

Lawrence, J. (2006). You Will Believe: The Cinematic Saga of Superman. Warner Brothers Pictures.

Loeb, J, \& Morris, T. (2005). Heroes and Superheroes. In T. Morris, M. Morris and W. Irwin (Eds.) Superheroes and Philosophy: Truth, Justice, and the Socratic Way (pp. 11-21). U.S.: Open Court Publishing Co.

Moore, A. and Gibbons, D. (1985). Superman Annual Vol.1, No. 11. New York: DC Comics.

Reynolds, R. (1994). Super Heroes: A Modern Mythology. Jackson: University Press of Mississippi.

Ross, A. \& Dini, P. (1999). Superman: Peace on Earth. New York: DC Comics.

Waid, M. (2005) "The Real Truth about Superman: And the Rest of Us Too. In T. Morris, M. Morris and W. Irwin (Eds.) Superheroes and Philosophy: Truth, Fustice, and the Socratic Way (pp. 3-11). U.S.: Open Court Publishing Co.

Weldon, G. (2013). Superman: The Unauthorized Biography. Hoboken, N.J.: Wiley. 